\title{
PAGANISM OF LITHUANIANS AND PRUSSIANS: RITUAL LAUGHTER
}

\begin{abstract}
Ritual laughter is considered an integral part of the rituals used to make sacrifice to the ancient gods. This article analyzes instances of ritual humor in written sources from the 16th to 17th century and echoes of the joke in calendars, family traditions and folklore in the 19th and 20th centuries. The aim is to investigate how jokes and fun were understood in the religion and mythology of the ancient Balts; what influenced the expression of this sort of joke and how; and what forms and manners for eliciting jokes and fun are recorded in written sources, customs, traditions and folklore. Information in the written sources from the 16th and 17th centuries (even if it is fragmentary) shows Lithuanians and Prussians knew of ritual laughter which is a component part of rituals for making sacrifices to the ancient gods. The aim of ritual laughter was to succeed in making the gods happy (especially gods protecting agriculture and its different branches). From the examples presented, although there might not be many of them, we can nonetheless determine that the ritual laughter of the Lithuanians and the Prussians was divided into two categories: a) the happy god (with the request and wish the god would be happy) and b) the ritual laughter and fun of participants in rituals. After Christianity came to dominate in the late 17th century, ritual humor became an important part of calendrical, family and other customs, recorded in folklore and echoed in everyday speech and phraseology.
\end{abstract}

Keywords: ritual laughter, customs, traditions, folklore, written sources 16th-17th, 19th-20th centuries, paganism of Lithuanians and Prussians.

Introduction. Jokes, joking around and pleasant and malicious tricks and pranks have been constant companions throughout human history. It is often said it is humor which separates people from the animals [1, p. 118]. Following Leonid Stolovich, one could put it differently: "Humor is the happy son of wisdom, and Man is not just Homo sapiens, but also Animal ridens" [37, p. 245]. That there was laughter and jokes in the most ancient times is attested by mythology as well as folklore as well as the earliest written texts [25, p. 10].

We will look here at tendencies to make jokes, laugh and have fun without larger prejudice or prior expectations of basically trying to research the topic of the joke throughout our culture. We will cover only a small segment of this entire confused and broad maze, i.e., the ritual joke in the preChristian era in Lithuanian and Old Prussian religion, its origins and some of its echoes in customs and folklore in the 19th and 20th centuries.

Research history. The topic of fun and jokes was of interest to philosophers from antiquity: Aristotle [1], Democritus [23], Plato [27], Cicero [10], Lucian [21]. One side (Democritus, Aristophanes, Lucian) saw the joke as a completely legitimate way of viewing the world which, complementing the serious view, allows us to see the world and its flaws more profoundly. According to the other tradition represented by Plato, Aristotle, Cicero the joke was seen as just an element of leisure time and entertainment. None of those professing either view denied the importance of humor in social life, but one group tended to encourage and propagate a humorous view of the world, while the other feared its dangerous and destructive effect on the state and the authorities [38, p. 23].

Humor was viewed negatively in the Middle Ages and so there are basically no new theoretical works about humor from that time [38, p. 25]. A clear restriction on different kinds of diversions and tricks (stultiloquium, scurrilitas) is visible in Christian theology from the 4th to the 10th century, emulating St. Paul in the Letter to the Ephesians. It says: "Neither filthiness, nor foolish talking, nor jesting, which are not convenient: but rather giving of thanks" is fitting for Christians (Eph 5:4) [6]. The asceticism of Christianity at that period put a damper on humor, and the world was filled with "devilish laughter". This is abundantly illustrated by sayings from this era where humor is a sign of idiocy, a characteristic of the devil [37, pp. 247-248]. Lithuanian folklore is full of such sayings: "How do you recognize an idiot if not for his joke?", "Not even straw sticks to a joke", "an idiot can laugh even in church", "Sin is from God, humor is from the world", "The jokes of the devotee are the sermon of the Devil", "you can't eat bread from a joke", "When the old man dances the Devil laughs". This gave rise to certain kinds of phraseology, e.g., "Velnias (velniai) juokias", "The Devil (devils) laugh", the devil laughs when a woman curses [43, p. 659]. Similar sayings are known among neighboring peoples [17, p. 78].

Those who research the features of sympathetic humor in modern Christianity note that a more liberal view of humor became apparent starting in the 12th and 13th centuries, and the joke began to be differentiated as appropriate or inappropriate. Claudiu Teodor Arieşan says:

The theologians of the period (Aleksandras Malietis, John of Salisbury, Albertus Magnus, Thomas Aquinas) created a new classification of comicality, explaining the bounds of tasteful humor. At more or less the same time the smile appears in Gothic sculpture (and especially on the lips of young angels) [11, p. 188].

There was a return in the Renaissance to the conception of humor formulated in antiquity, and philosophers again took an interest in the phenomenon of humor beginning in the 17th century (René Descartes, Immanuel Kant, Georg Hegel, and later Arthur Schopenhauer, Friederich Nietzsche, Sigmund Freud and others) [38, pp. 25-26].

Also noteworthy are academic works by $\mathrm{H}$. Bergson [5], B. Dzemidok [14], O. Frejdenberg [15], V. Propp [30], M. Rjumina [34], and others in the 19th and 20th centuries which examine the phenomenon of humor in one aspect or another. They arrive at basically the same opinion that "humor is living, pulsing energy" [5].

In the Lithuanian language we can only point to one work of greater breadth, the teaching aid "Juoko kultūra" [Culture of Humor] by Inga Vidugiryte. Certain passages by J. Baldauskas, J. Balys, P. Dundulienè, L. LaurinavičiūtèPerošienè, V. Mihalovskis, R. Ragauskienè, D. RazauskasDaukintas, A. Vaicekauskas, A. Vyšniauskaitè and many other ethnologists, folklorists and mythologists touch upon the significance of humor in rituals, customs and folklore, although humor, jokes and fun were not the main subject of their research. We also do not find in works by these authors the goal set to examine rituals in which fun dominates. Even so, the view of humor in articles and monographs by these authors differs significantly.

For instance, P. Dundulienè in examining Shrovetide traditions notes there were attempts to cause laughter during childbirth, weddings and funerals. The aim was to drive off evil forces which sought harm and to insure fertility. Following the introduction of agriculture, P. Dunduliene believes, "the magic power of laughter was transferred to agrarian rituals, ... laughter was supposed to awaken the vitality and fecundity of the earth, and also to impart the power to bloom and produce fruit to the earth" [13, pp. 80-81]. The 
transfer of humor, of course, could be debated, because the author fails to provide information proving or giving foundation to this shift by the magic of laughter, but that's a different discussion. Summarizing the description of the aforementioned holiday, P. Dundulienè favors holding the ritual humor and fun to be the result of the loss of tradition:

The customs of the pagan Lithuanians intertwined with

Christian religious motifs survived more or less until the

20th century and having completely lost their religious

significance, in some places, especially Žemaitija, they

have survived to our day having become entertainment

during winter holidays" [13, p. 85]

A. Vaicekauskas summarizes his work on Shrovetide similarly, saying the abundant sources in the late 19th and 20th centuries show the development of the costumewearing tradition of the calendrical winter holidays which led to the disappearance of the ritual functions of the traditions and the domination of the entertainment function in the 20th century [41, p. 20 , pp. $40-48$, p. 79$]$.

Some of the abovementioned authors hold a contrary view. For instance, Lina Laurinavičiūtè-Petrošienè who researched the written sources from the 15th to the 18 th century on the meaning and content of Shrovetide says in her monograph the raucous fun should be considered equal in merit to the other ritual functions, and in the case of Shrovetide "the function of fun and entertainment is the foundation, essence and core of this holiday" [20, pp. 16-20].

Auksuolè Čepaitienè expanded on this statement saying holidays (not just Shrovetide) cover all possible and equally necessary aspects of the life of the people. They are at one and the same time a ritual, entertainment and communication, and social events bringing the community together [12, p. 477]. Dainius Razauskas-Daukintas holds a similar view as well. Discussing the mythical image of "the laughter of the Sun" in Kristijonas Donelaitis's "Metai", Dainius Razauskas-Daukintas doesn't just connect laughter with the light of the sun, but also "with light in the abstract, mental sense", and

a new crucial thought, a decision, a new knowledge, spiritual illumination can 'be born' in this way in the inner

world, while in the outer world the image of mental affliction can be exactly night or winter, from whose clutches a new being emerges or escapes in the morning or in the spring [33, pp. 33-34].

As we see from the humble history of our research, investigators mainly focused elements of fun found in descriptions of Lithuanian traditions and folklore in the late 19 th and early 20 th centuries. Such a study, however, should begin primarily from an examination of the religious rites of our and other peoples in the pre-Christian era, and then go on to reflections of these in the 19th, 20th and 21st centuries. This is the only way we can come to terms with the genesis and meaning of the traditions of this time-period.

The genesis of ritual laughter. So, in this case we should discuss ritual humor and its reflections. What is it? How did it arise? The question is problematic because the opinions of researchers differ on the origin and development of humor. Thus, there are many different definitions formulated for ritual humor. I will present a few of them which correlate with the material used and the aims defined in this article.

$V$. Propp's view of the genesis and semantics of humor is especially useful to us here in this article. Propp says laughter in the mythical worldview is not just life's companion but life itself, vitality, and hence the creator of the entire world [30, p. 225).

Russian researcher M. Ryumina says ritual humor is a borderline state between life and death, a strange threshold and even a necessary precondition for moving out of one opposition into another. The laugh is always "between" [34, p. 132]. Inga Vidugirytè believes ritual laughter is a specific behavior (laughing) connected with religious the purpose of which (as with any other religious segment - R. B.) is to control or affect the forces of the supernatural world which do not obey man [42, p. 19].

Anthropologists tend to explain ritual laughter through specific demands of the social structure. Several theories exist. One of them claims conflicts are resolved and collected social tension dispersed through ritual humor. Another says communication with the supernatural world demands maximum exertions which are compensated by interruptions of laughter [42, p. 24].

Olga Frejdenberg's starting point in discussing humor is the assertion laughter is one of the metaphors of cosmogony. It is exactly that important in renewal rituals whose semantics have survived in culture till today: we are accustomed to cry during funerals and have fun during weddings, and we believe this to be the voice of our emotions and consciousness, but alongside our traditions there are others in which there is baleful wailing during weddings and joking around on the day of death. Genetically, both one and the other are not the act of the individual person, but collective societal facts which are understood as the origin of cosmogony whose metaphors are "laughter" and "tears" [15, p. 105].

A large number of cosmogonic myths posit the world is created out of a monster (dragon) defeated by the gods or heroes. So the world - all that grows, breathes, laughs and cries - comes out of death. For the same reason the ancient agrarian rituals of the change of seasons (sowing, reaping the harvest) used to contain one prerequisite element of ritual: the murder of the hero (ruler, accomplice of the god) $[15$, p. 98, p. 153]. In other words, it is again emphasized in the archaic conception of the world that a new life is inconceivable with the death of an old life. And it was exactly from these rituals (cosmogonic and later agrarian) that also gave rise eventually to carnival-style fun and games.

This seems to show that ritual humor and fun have been connected from the very beginning with rape, violence and conquering. A significant circle of 20th century investigators have come to that conclusion and have written about it. For instance, Joshua Gregory says humor has come to us out of the mists of time with blade in hand [16, p. 13]. L. Karasev makes a similar comment, saying that it took millennia of barbarically deafening, roaring laughter marked by animal passion and the constant battle to survive to make a baby laugh $[17$, p. 20]. Thus, laughter is an ennobled howling [22, p. 30] or put another way, ritual laughter is only purified in the process of civilization.

Examples from the ancient religion of the Greeks and Romans are a good place to start looking at the expression of ritual humor and fun. Memorable in this regard is the Greek god of fun and excess, Comus, son of Dionysius and Circe. In ancient Greece in festivals dedicated to him men and women would trade clothes. The Greeks also knew of the personification of laughter, Gelos, whose temple was in Lacedaemon. Gelos's Roman counterpart was Risus [24, p. 145]. And of course, there was also Dionysius, Bacchus, Thalia (goddess or muse of comedy) and so on. One of the best-known Greek myths, the myth of Demeter and her daughter Persephone, also illustrates the significance of laughter. Laughter is understood in the myth as a sign of all forms of vitality. Its influence is universally significant, equally important to the human being, to animals and to foliage. When Hades kidnaps and locks Persephone in his subterranean realm, the goddess of abundance and fertility, Demeter, is deeply afflicted by the loss, no longer laughs, and from then on the grass and flowers no long grow and bloom on the earth and the birds no longer sing. lambe her servant finally causes Demeter to laugh. The goddess's 
laughter brings spring back to the earth and all nature awakens from being frozen [29, pp. 79-114].

There is an even older Persian tradition about the prophet Zarathuštra (Zoroaster) who, when he was born, did not cry (as is usual), but laughed instead, and as he laughed he emitted a holy light; his aura shone light above the city [32, pp. 255-256].

The Yakuts long ago worshiped the goddess lyeiksit (lyeksit) who protected women giving birth, laughing severely at the birth itself [28, p. 186]. The rite for ushering lyeiksite out, performed on the third day after birth, is very significant. One of the female participants in the ritual begins to laugh and guffaw, which is immediately copied by the other women. The point of the laughter is the pregnancy of and successful future birth by the participants in the ritual [28]. We should draw the conclusion that laughter in this case is a necessary condition for fertility.

There is a form of laughter recorded in the Old Testament in the word sâhak; this is laughter arising from joy and true exaltation, from the spirit of holiness. This is the name which Isaac received from God Himself, Yçhq-El ("God made me to laugh"), as foreseen in the book of life: "And we told her her son's name which was destined and written on the heavenly tablets: Isaac" [9, p. 16, pp. 3-4].

There is another cosmogonic myth ascribed to the Egyptians and Greeks which should be mentioned; it says: "The god laughed seven times and the seven gods guarding the world were born. The seventh time the god laughed especially joyfully and Psyche was born" [26, p. 66]

We could cite more examples and similar examples, but it's apparent from the myths and passages of them already presented we can say confidently laughter was the companion of the world as well as of the birth of the individual, or, as stated earlier, the crucial prerequisite for both.

Moving on to the written sources of the Balts, we should also mention Raimonda Ragauskienè's article "Dvaro 'juokdario institutas' Lietuvos Didžiojoje Kunigaikštystėje XIV a. pabaigoje - XVIII a. pradžioje" [The Clown "Academy" of the Manor Estate in the Grand Duchy of Lithuania from the Late 14th to the Early 18th Century] where she says: "Lithuanians apparently had no deity on their Olympus which was 'responsible' for the field of humor", but, she believes, "different mythological beings may be associated with the world of laughter from the anthropological point of view. These are difficult to characterize mythological trouble-makers who cause chaos: devils, witches, aitvarai and even the new moon". Ragauskiene assigns the latter to the category of humorous mythological characters based on the texts of brief prayers: "You shine for us always, you make us happy. We see him and we all calm down, all of us have had fun to our content" (Rokiškis) [31, nr. 4, pp. 262-270].

We could discuss the formulation of this claim, arguments for and against and the material used, but we won't do that here. Let the sources "speak" for themselves. The information they contain and an examination of that information will together answer the question of whether Lithuanians (and other Balts) had a patroness of laughter and fun in their pantheon.

Ritual laughter in the Baltic religion. It seems laughter was viewed favorably by the ancient Balts and by some of the gods they adored. Grunau's chronicle which contains among other things the Laws of the Brutenai on "how they should live" says:

Third, we must feel respect and fealty towards our brightest gods and our Krivis krivaitis (crywen kirwaito) because after this life they will give us beautiful women, many children, sweet drink, good food, white clothes in summer, warm cloaks in winter, and we will sleep in wide, soft beds, and out of health we will laugh and dance (emphasis added). From evil people, who will not worship them, they will take everything they have, and they will torture them greatly there [3, p. 93]

Laughter is understood here as an expression of health and abundant life, as a reward for loyalty to the gods and hierophants. The Grunau chronicle also portrays one of the three supreme Prussian gods as smiling (happy), the cereal god Patrimpas. Moreover, this god is distinguished from the other two gods:

one as a young man, beardless, with a crown of grain on his head, happy: he was the god of cereals and was called Patrimpas (Potrimppo). The second was an angry middle-aged man, his face was like fire, and his crown of flames, his beard was curly and black, and the two of them looked at each other, examining what sort he was, one smiling happily from the other's wrath, while the second one smoked a pipe. The third picture portrayed an old man with a long, grey beard, and his color was wholly like that of a dead man, he was crowned with a white scarf wrapped like a turban, and stared gloomily at the other two and was called Patulas (Patollo) [3, p. 103]

Jan Lasicki, retelling the information from Alexandro Guagnini, writes that the god Žemininkas was asked to accept the offering made to him with joy: "Please accept, o Žemininke (Zemiennik), this offering and eat it joyfully!" [3, p. 596]

It should be recalled here that the word malda, meldžiu, maldau [prayer, I beseech, I prayed] in the Lithuanian language, according to Kazimieras Būga, developed from the closely-related concept of softness ["minkštumas"] or flexibility ["lankstumas"]: Latin mollis "soft, flexible", Gothic mildeis "pleasant", OHG milti "friendly, good, pleasant". Thus for the ancient Lithuanian the sentence "I pray to the god" ["meldžiu dievą"] meant "I soften the god", "I bend the god" ["minkštinu dievą", "lenkiu dievą€] [7, pp. 102-103], and, based on the text of the prayer to Žemininkas presented above, we can say that in separate instances it also meant "I am making the god happy, glad".

Jonas Maleckis-Sandeckis, based on the Sūduvian Book, retells the sacrifices prepared for the Prussian gods in spring and autumn, during which they made offerings to the gods, said prayers, cooked wheat cakes and at the culmination "partied and had fun the whole night long" [3, p. 209)

Matthäus Prätorius presents the most examples of ritual humor and fun in the latter half of the 17th century. In this respect Matthäus Prätorius is the most "productive". For instance, Matthäus Prätorius testifies they "called upon St. George" in describing a livestock holiday, herded the animals into a pen and began to feast, during which "everyone turns naughty and plays tricks, and the more fun it is, the better..." He adds: "during eating whoever plays the best tricks is considered the best person" [4, pp. 289290]. Matthäus Prätorius says there is a joyful celebration (and joyful to God) of the harvest holiday. This holiday is addressed to the old gods. That is demonstrated by the note that it is celebrated "on a day when no one expects outsiders to arrive, and always in the evening..." [4, p. 292]. The main event in the ritual is the prayer to Žemyna and God: "Zemyne zedkellei zydek ruggeis, mezais ir wisseis jauweis, buk linksmas, Diewe, ant mussu, pri tu mussu darbu Szwents Angels pributu ir piktu zmogu priszalin nukraipik, kad mus ne apioktu" ["Žemyna make the rye, barley and all cereals bloom, be happy, God, with us, and may the Holy Angel watch over our works and send the evil man away so he would not steal from us"] [4, p. 292]. Many mythologists and folklorists have quoted and discussed this text, but, I believe, the aspect of the happy God hasn't been addressed before. This is, according to Matthäus Prätorius, the customary manner of worship. Read: this is the request always made in the prayers. This is confirmed in Matthäus Prätorius's descriptions of other rituals. For instance, during the holiday of the god Gobjaujis, as a rooster is being prepared for sacrifice, "the mature people of the male gender take part in 
the ritual, raising their hands and eyes upwards, and say: 'O Gabjauji (Gabjauga), be happy with us and beneficent'" [4, p. 296]. During the same celebration, the head of household, before drinking from the first horn, first lets drip a little beer for Žemyna and addresses her with these words: "O Žemynele, be happy and make our rye bloom" [4, p. 296]. This holiday is concluded by again thanking the god Gabjaujis and asking him to be happy: "Dear God Gabjaugia, we have performed nicely for you, be happy, our Little God, bless us, our children, our land, our houses, our farms, our livestock, our crops" [4, p. 297]. The same request is made to Žemynèlè (diminutive form of Žemyna) in consecrating horses: "O Žemynèle, be happy with us and with my horse" [4, p. 306]. A similar prayer is address to Žemèpatis in celebrating the move into a new house or location:

Dear God (some also add Žemèpatis; Zemepatie), I give

to you a quick and healthy rooster and hen, give me, as I and

we have, everything which belongs to me, that we would

always be quick, healthy and comfortable, so that we might

always feel your hand of blessing in our works" [4, p. 303].

Prätorius's description of a ritual to consecrate bees is composed of several rituals following upon one another which are dominated by seriousness, calm and concentration. The rituals end with a prayer, and then, Prätorius says, "they being to have fun with their family clan" [4, p. 307]

From these examples, it becomes clear that in the case of ritual humor, the same scheme applies which are seen in sacrificial rituals in general: to give to the giver, in other words, to affect the Gods so they would be happy and laugh, and then laughter and fun accompanies the ritual participants. There are echoes of the laughing god which survive in sayings: Laimè nusišypsojo, something succeeded [18, p. 53]. Laimos dienos, when it is good, happy, when a person is happy [18, p. 52].

From the religious rites and sacrifice rituals, laughter and humor naturally entered into calendrical and family holiday traditions and folklore. There is a special abundance of fun wedding rituals. It seems to be too much for Prätorius at times, when he cannot help but condemn the awful tradition where "silly young men attempt in places to disturb the matchmaker's prayer, offering all sorts of profane observations and silly pranks, to confuse the matchmaker as he prays and make him ashamed" [4, p. 312]. At the same time he also admits in this passage there must be an appropriate time for making jokes and having fun during a wedding, and this is one of the main functions of the matchmaker character in the drama: "During supping the matchmaker's job is to deliver all manner of brief speeches, to entertain the party" [4, p. 312].

This is confirmed by another 17 th-century author, Erhard Wagner. Describing the life and customs of the Lithuanians of East Prussia living in the districts of Insterburg and Ragnit, he says

All Saints' Day becomes for them a day of public fun and entertainment ... Then they eat to their fill, overeat, marry wives and marry off daughters to men. So around that time groups flock to the churches and, having completely tired the inviter to the wedding out, they celebrate the remaining days of the wedding with funny rituals [4, p. 21]. Especially relevant to the topic under discussion is Wagner's description of the wedding ritual custom following the lying of the young couple in a barn to make the bride laugh: Here the groom's elder brother comes, he's carrying sort of cat or just something wrapped up and swaddled like a child, and he does all sorts of silly things to make the bride laugh, and she tries to remain serious for as long as she can; even she smiles even a little, the older brother immediately takes off his cap and jacket, and she then stands there with only her veil" [4, p. 316]

Zenonas Slaviūnas has already pointed to this unique custom of entertaining the bride or making her laugh [36, p. 584]. The bride's laughter is a precondition for the continuation of the rituals and a sign the family will bear offspring.

The custom of making the bride laugh survived in some places into the 20th century. For instance, around Kupiškis whoever made the bride laugh was afforded great respect and the bride even presented a gift to him:

On the first morning the daughter-in-law is seated at the table and she must be sad. The sad daughter-in-law has to be made happy somehow. Everyone would like to make the new bride laugh, but it's not that easy. Everyone does their best with whatever they can come up with. They say something funny; they demonstrate some funny items; they sing silly songs and so on. The great father-in-law even had a special pipe to make her laugh. When the bride broke out in laughter, everyone began applauding with their hands and to shout for joy. Great honor was afforded to the person who made the bride laugh, and sometimes he received gifts from the bride as well [8, p. 269].

And there were many more jokes, games and all sorts of tricks and fun in Lithuanian family and calendrical holidays [2, pp. 41-41, pp. 205-206, p. 225; 12, pp. 20-21; 19, p. 60; 42 , pp. $20-21 ; 44$, pp. 371-373), entertaining evenings among young people and furthermore the jokes and pranks of shepherding livestock in the summer [39] there is an abundance of comic folklore, and so on, and so on [35, pp. 437-444]. The point of all these customs, actions, texts and behavior was one and the same: to elicit laughter.

Conclusions. We can state that ritual laughter has neither a beginning nor an end. It is a closed circle, accompanying the individual's life from birth to death and rebirth; from laughter in this life to fun in the next. A Tyrolean proverb illustrates this last idea well: "The gates of heaven open only for those who know how to smile" [11, p. 191].

Information in the written sources from the 16th and 17th centuries (even if it is fragmentary) shows Lithuanians and Prussians knew of ritual laughter which is a component part of rituals for making sacrifices to the ancient gods. The aim of ritual laughter was to succeed in making the gods happy (especially gods protecting agriculture and its different branches).

From the examples presented, although there might not be many of them, we can nonetheless determine that the ritual laughter of the Lithuanians and the Prussians was divided into two categories: a) the happy god (with the request and wish the god would be happy) and $b$ ) the ritual laughter and fun of participants in rituals.

After Christianity came to dominate in the late 17th century, ritual humor became an important part of calendrical, family and other customs, recorded in folklore and echoed in everyday speech and phraseology.

\section{References}

1. Aristotle. (1937). O chastjah zhivotnyh [About Animal Parts]. Moskva: Biomedgiz. (In Russ.)

2. Balys, J. (1993). Lietuvių kalendorinès šventès. Tautosakiné medžiaga ir aiškinimai [Lithuanian Calendar Holidays. Folklore Material and Interpretations]. Vilnius: Mintis. (In Lithuanian).

3. Baltu religijos ir mitologijos šaltiniai. (2001). [Sources of Baltic Religion and Mythology]. T. II. Sudarè Norbertas Vèlius. Vilnius: Mokslo ir enciklopedijų leidykla. (In Lithuanian).

4. Baltu religijos ir mitologijos šaltiniai. (2003). [Sources of Baltic Religion and Mythology]. T. III. Sudarè Norbertas Vèlius. Vilnius: Mokslo ir enciklopediju leidykla. (In Lithuanian).

5. Bergson, A. (1992). Smeh [Laughter]. Moskva: Iskusstvo. (In Russ.)

6. Biblija RK-K - Rubšio ir Kavaliausko Biblija, Lvk (kataliku) leidimas. (1998). [Bible RK-K - Bible of Rubšis and Kavaliauskas, Lvk (Catholic) edition]. http://biblija.It/index.aspx?cmp=reading\&doc=BiblijaRKK1998 Ef 5 .

7. Būga, K. (2017). Rinktiniai raštai [Selected Notes]. T. II. Vilnius: Valstybinè politinès ir mokslinès literatūros leidykla. (In Lithuanian).

8. Buračas, B. (1935). Kupiškèny vestuvés [Kupiškènai Wedding]. T. I. Tautosakos darbai. Kaunas. (In Lithuanian).

9. Charles, R. H. (ed.). (1913). The Book of Jubilees. Oxford: Clarendon Press. http://individual.utoronto.ca/tldonaldson/Jubilees.html.

10. Cicero, Marcus Tullius. (1972). Tri traktata ob oratorskom iskusstve [Three Treatises on Oratory]. Moskva: Nauka. (In Russ.). 
11. Claudiu, T. A. (2012). Risus Angelicus. Gydančios atjaučiančio juoko savybès moderniojoje krikščionybėje [Risus Angelicus. Healing Properties of Compassionate Laughter in Modern Christianity]. Naujasis Židinys-Aidai, 3, pp. 188-191. (In Lithuanian)

12. Čepaitienè, A. (2013). Gyvenimo etnografija: vietos, struktūros ir laikas. Besikeičianti Lietuva XX amžiuje [Ethnography of Life: Places, Structures and Time. Changing Lithuania in the 20th Century]. Vilnius: Lietuvos istorijos instituto leidykla. (In Lithuanian).

13. Dundulienè, P. (1994). Lietuviu šventès: tradicijos, papročiai, apeigos [Lithuanian Holidays: Traditions, Customs, Ceremonies]. Vilnius: Mintis. (In Lithuanian).

14. Dzemidok, B. (1974). O komicheskom [About the Comic]. Translated from Polish. Moskva: Progress. (In Russ.).

15. Frejdenberg, O. (1997). Poetika sjuzheta i zhanra [Poetics of Plot and Genre]. Moskva: Labirint. (In Russ.).

16. Gregory, C. J. (1924). The Nature of Laughter. New York: Kegan Paul.

17. Karasev, L. V. (1996). Filosofija smeha [The Philosophy of Laughter]. Moskva: RGGU. (In Russ.).

18. Kruopas, J. (ed.). (1966). Lietuviu kalbos žodynas [Lithuanian Language Dictionary]. T. VII. Atsak. red. Vilnius: Mintis. (In Lithuanian).

19. Kudirka, J. (1992). Užgavénés [Shrovetide]. Vilnius: Mokslas. (In Lithuanian)

20. Laurinavičiūtè-Petrošienè, L. (2015). Žanro virsmas: Žemaitijos Užgavénių dainos [Transformation of Genre: Samogitian Shrovetide Songs]. Klaipèda: Klaipèdos universiteto leidykla. (In Lithuanian).

21. Lucian. (1935). Sobranie sochinenij [Collected Works]. T. 1-2. Ed.

B. L. Bogaevskij. Moskva - Leningrad: Academia. (In Russ.).

22. Ludovici, A. M. (1932). The Secret of Laughter. London: Constable.

23. Lur'e, S. Ja. (1970). Demokrit: Teksty. Perevody. Issledovanija. Leningrad [Democritus: Texts. Translations. Research]. Leningrad: Nauka. (In Russ.).

24. Meletinskij, E. M. (ed.). (1991). Mifologicheskij slovar' [Mythological Dictionary]. Moskva: Sovetskaja jenciklopedija. (In Russ.).

25. Michalovskis, V. (2014). Juokdariai: istorija ir simbolika [Jokers: History and Symbolism]. Šiaurès Atènai, rugpjūčio 8 d., 28 (1190), p. 10. (In Lithuanian)

26. Norden, E. (1924). Die Geburt des Kindes. Geschichte einer religiösen Idee [The Birth of the Child. Story of a Religious Idea]. Leipzig. (In German).

27. Plato. (1965). Zakony. Izbrannye dialogi [The Laws. Selected Dialogues]. Moskva: Hudozhestvennaja literatura. (In Russ.)

28. Propp, V. Ja. (1976). Ritual'nyj smeh $v$ fol'klore (po povodu skazki o Nesmejane). Folklor i dejstvitel'nost'. Izbrannye stat'i [Ritual Laughter in Folklore (About the Tale of Nesmeyan)]. In: Folklore and reality. Selected articles]. Moskva: Nauka. (In Russ.).

29. Propp, V. Ja. (1995). Russkie agrarnye prazdniki [Russian Agrarian Holidays]. Sankt-Peterburg: Azbuka. (In Russ.)

30. Propp, V. Ja. (1999). Problemy komizma i smeha. Ritual'nyj smeh v fol'klore (po povodu skazki o Nesmejane) [Problems of Comic and Laughter.

Рімантас Бальсис, д-р гуман. наук, проф.

ORCID: 0000-0002-4285-4835

e-mail: rimantasbalsys61@gmail.com

Інститут досліджень культури Литви, Вільнюс, Литва
Ritual Laughter in Folklore (About the Tale of Nesmeyan)]. Moskva: Labirint. (In Russ.).

31. Ragauskienè, R. (2011). Dvaro juokdario "institutas" Lietuvos Didžiojoje Kunigaikštystèje XIV a. pabaigoje - XVIII a. pradžioje [The "Institute" of the Manor's Joker in the Grand Duchy of Lithuania at the End of 14th - Beginning of 18th Centuries]. Naujasis Židinys-Aidai, 4, pp. 262-270. (In Lithuanian)

32. Rak, I. V. (1998). Zoroastrijskaja mifologija. Mify drevnego i rannesrednevekovogo Irana [Zoroastrian Mythology. The Myths of Ancient and Early Medieval Iran]. Sankt-Peterburg - Moskva. (In Russ.)

33. Razauskas-Daukintas, D. (2016). Mitiniai vaizdiniai Donelaičio "Metuose". Pastabos paraštése [Mythical Images in Donelaitis' "Year". Notes in the Margins]. Vilnius: Lietuvių literatūros ir tautosakos institutas. (In Lithuanian).

34. Rjumina, M. T. (1998). Tajna smeha, ili Jestetika komicheskogo [The Secret of Laughter, or Aesthetics of the Comic]. Moskva: Znak. (In Russ.).

35. Sauka, D. (1970). Tautosakos savitumas ir verté [Peculiarity and Value of Folklore]. Vilnius: Vaga. (In Lithuanian).

36. Slaviūnas, Z. (1955). "Svodbinès rèdos" pastabos ir paaiškinimai. Lietuviškos svodbinès dainos, užrašytos Antano Juškos ir išleistos Jono Juškos [Notes and Expanations of the Weddings Ceremony. Lithuanian Weddings Songs Collected by Antanas Juška and Published by Jonas Juška]. T. II. Vilnius: Valstybinè grožinès literatūros leidykla. (In Lithuanian).

37. Stolovich, L. (1999). Filosofija. Estetika. Smeh [Philosophy. Aesthetics. Laughter]. Sankt-Peterburg, Tartu: Nauka, Kripta. (In Russ.).

38. Sychev, A. A. (2003). Priroda smeha ili Filosofija komicheskogo [The Nature of Laughter or the Philosophy of the Comic]. Saransk: Izd-vo Mordovskogo un-ta. (In Russ.)

39. Šaknys, Ž. (1996). Jaunimo brandos apeigos Lietuvoje: XIX a. pab. $X X$ a. pr. [Youth Maturity Rites in Lithuania: End of 19th - Beginning of 20th Centuries]. Vilnius: Pradai. (In Lithuanian).

40. Šaknys, Ž. (2001). Kalendoriniai ir darbo papročiai Lietuvoje XIX a. pab. - XX a. I-oje puséje: Jaunimo vakaréliai [Calendar and Work Customs in Lithuania at the End of 19th -Beginning of 20th Centuries. Side I: Youth Parties]. Vilnius: Diemedis. (In Lithuanian).

41. Vaicekauskas, A. (2005). Lietuvių žiemos šventès. Bendruomenés kalendorinio ciklo apeigos XIX a pab - XX a pr. [Lithuanian Winter Holidays. Community Calendar Cycle Rites at the End of 19th - Beginning of 20th Centuries]. Kaunas: Vytauto Didžiojo universitetas. (In Lithuanian).

42. Vidugirytè, I. (2012). Juoko kultūra [A Culture of Laughter]. Vilnius: Vilniaus universiteto leidykla. (In Lithuanian).

43. Vitkauskas, V. (ed.). (1997). Lietuviu kalbos žodynas [Lithuanian Language Dictionary]. T. XVIII. Vilnius: Mokslo ir enciklopedijų leidybos institutas. (In Lithuanian).

44. Vyšniauskaitè, A., Kalnius, P., \& Paukštytè, R. (1995). Lietuviu šeima ir papročiai [Lithuanian Family and Customs]. Vilnius: Mintis. (In Lithuanian).

Надійшла до редколегії 15.01.21

\section{ЯЗИЧНИЦТВО ЛИТОВЦІВ I ПРУСІВ: РИТУАЛЬНИЙ СМІХ}

Ритуальний сміх вважається невід'ємною частиною ритуалів, що використовуються для жертвоприношень древнім богам. Аналізуються випадки ритуального гумору в письмових джерелах XVI-XVII cm. і відгомони жартів у календарях, сімейних традиціях і фольклорі XIX-XX cm. Мета дослідження полягає в комплексному аналізі ритуального сміху, жартів і веселощів у письмових джерелах XVI-XVII ст. литовців і прусів. Окрему увагу приділено розумінню ритуального сміху в релігії та міфології давніх балтів, чинникам, а також передумовам виникнення жартів і веселощів, тим формам і засобам їхнього вираження, які зафіксовано в письмових джерелах, звичаях, традиціях і фольклорі. Інформація, наведена в писемних джерелах XVI-XVII cm. (незважаючи на те, що вона досить фрагментарна) показує, що литовці і пруси знали про ритуальний сміх, який є компонентом ритуалів жертвоприношень давнім богам. Метою ритуального сміху було досягти успіху в тому, щоб зробити богів щасливими (особливо богів, які захищають сільське господарство та його галузі). Із представлених прикладів, хоча їх і небагато, ми все ж можемо зробити висновок, що в литовців та прусів було дві категорії ритуального сміху: а) щасливий бог (із проханням і побажанням, щоб бог був щасливим) і б) ритуальний сміх і веселощі учасників ритуалів. Після того, як в кінці XVII ст. християнство стало домінантною реліеією, ритуальний гумор став важливою частиною календарних, сімейних та інших звичаїв, які зафіксовані у фольклорі та відображені у повсякденному мовленні та фразеології.

Ключові слова: ритуальний сміх, звичаї, традиції, фольклор, письмові джерела XVI-XVII cm., XIX-XX cm., язичництво литовців і прусів. 